World Maritime University

The Maritime Commons: Digital Repository of the World Maritime University

Conference Proceedings

2021

Developing Moodle as an e-learning alternative to the kinesthetic approach for Maritime English subject during the Movement Control Order (MCO) period in Malaysia: the conceptualization of distress and routine messages of the IMO SMCP

Shamsul Rizal bin Haji Mohd Rosedi

Malaysian Maritime Academy

Follow this and additional works at: https://commons.wmu.se/imla2021

Part of the Education Commons

Recommended Citation

Rosedi, S. (2021). Developing Moodle as an e-learning alternative to the kinesthetic approach for Maritime English subject during the Movement Control Order (MCO) period in Malaysia: the conceptualization of distress and routine messages of the IMO SMCP. In Pazaver, A., Manuel, M. E., Bolmsten, J., Kitada, M., Bartuseviciene, I. (Eds.), Proceedings of the International Maritime Lecturers' Association. Seas of transition: setting a course for the future (pp. 226-238). World Maritime University. http://dx.doi.org/ $10.21677 /$ imla2021.20

This Paper is brought to you courtesy of Maritime Commons. Open Access items may be downloaded for noncommercial, fair use academic purposes. No items may be hosted on another server or web site without express written permission from the World Maritime University. For more information, please contact library@wmu.se. 


\title{
Developing Moodle as an e-learning alternative to the kinesthetic approach for Maritime English subject during the Movement Control Order (MCO) period in Malaysia: The conceptualization of distress and routine messages of the IMO SMCP
}

\author{
Shamsul Rizal bin Haji Mohd Rosedi \\ Malaysian Maritime Academy, Malacca, Malaysia, shamsulrizal@alam.edu.my
}

\begin{abstract}
This paper shares impactful insights on Moodle e-learning which was developed as an alternative to face-to-face Kinesthetic approach in teaching distress and routine messages of the IMO SMCP during the period of Movement Control Order (MCO) in Malaysia. The enforcement of the MCO has resulted in the teaching and learning of the STCW courses (Standards of Training, Certification and Watch-keeping for Seafarers) being drastically shifted from normal face-to-face facilitation to full online distance learning (ODL). Hence, the study aims to discover the potential of Moodle to replicate the effectiveness of the kinesthetic approach in teaching IMO SMCP's Distress and Routine messages to new students. This is a two-tier experiment which covers both e-learning intervention and assessments and concludes with a quantitative study. The results of this study show that the Moodle e-learning, developed to replace the kinesthetic approach, has been successful in teaching the distress and routine messages of the IMO SMCP to novice students. The findings of this study provide clearer direction in online distance learning to Akademi Laut Malaysia (ALAM) and its stakeholders for continuous quality improvement. Moreover, the study also encourages more intensive and extensive involvement of MET trainers in the Moodle learning management system (LMS) development and usage in the teaching of STCW courses.
\end{abstract}

Keywords: Moodle, Maritime English, IMO SMCP, MCO, Distress and Routine messages

\section{Introduction}

The global pandemic of Covid-19 has revolutionized the delivery of STCW courses (Standards of Training, Certification and Watch-keeping for Seafarers) in Malaysia. Indeed, the sudden shift to online distance learning has changed the eco-system of teaching, learning and assessments (TLAs) of the STCW courses which has never been imagined before. Indeed, the Movement Control Order (MCO) enforced by the Malaysian government has encouraged educators in maritime education and training institutions (METIs) to take a bold step in transforming their lessons to digital learning platforms to be accessed effectively by students. This paper, being the first of its kind in Malaysia, shares a practical experience in replacing the kinesthetic approach with Moodle E-Learning, to successfully complete the cycle of teaching, learning and assessments (TLAs) for distress and eoutine messages of the IMO Standard Marine Communication Phrases (SMCP).

\section{Literature Review}

The Significance of Moodle in Tertiary Education and at ALAM 
Moodle is 'a software package which has been developed to help teachers and educationists to create quality online courses' (Lisnani et al., 2020; Harry et al., 2019 and Sucheta et al., 2018). Furthermore, its acronym stands for Modular Object-Oriented Dynamic Learning Environment and it was developed initially to suit an open-source e-learning platform in the form of a Course Management System (CMS) (Lisnani et al., 2020; Harry et al., 2019; Sucheta et al., 2018; Gunduz and Ozcan, 2017 and Chourishi et al., 2011). Related studies by Reham (2019) and Deepak (2017) reported that Moodle provides the appropriate platform for teaching, learning and assessment resources and tools which feature file uploads, discussion forums, assignment submissions, calendar entries, student grading, interactive quizzes, class modules and tutorials. In its wide practice, Moodle is used for learning language, science, and computer subjects (Mulhayatiah et al., 2019; Handayanto et al., 2018 and Gunduz \& Ozcan, 2017). To be instrumental, Moodle promotes self-directed learning which reduces dependability on teacherguided lessons and as such, it can be used for tutorials to increase students' knowledge of the subject matter (Handayanto et al., 2018; Takaedengan and Santosa, 2018). Most importantly, researchers such as Frisnoiry and Darari (2020), Reham (2019), Mulhayatiah et al. (2019), Hakim et al. (2019), Cohen and Sasson (2016) and Chourishi et al. (2011) claimed that the proper use of Moodle has significantly increased student motivation and learning outcomes. This is the most desired result for educators and educationists for online distance learning especially during the lockdown period in Malaysia.

At ALAM, Moodle has been introduced and integrated into the formal teaching, learning and assessments process (TLAs) since 2016. To date, Moodle has also been an integral part of trainers' annual assessments especially to enrich students' learning experience. This move provides more innovative, engaging, and motivating elements to the delivery of STCW courses, which have been comfortably conducted via traditional face to face learning. Suffice to mention also that all subjects in the two major STCW programmes, namely the Diploma in Nautical Studies and Marine Engineering have their own Moodle LMS platforms to support e-learning. Figure 1 below illustrates the Moodle LMS for Maritime English that was used in this study.

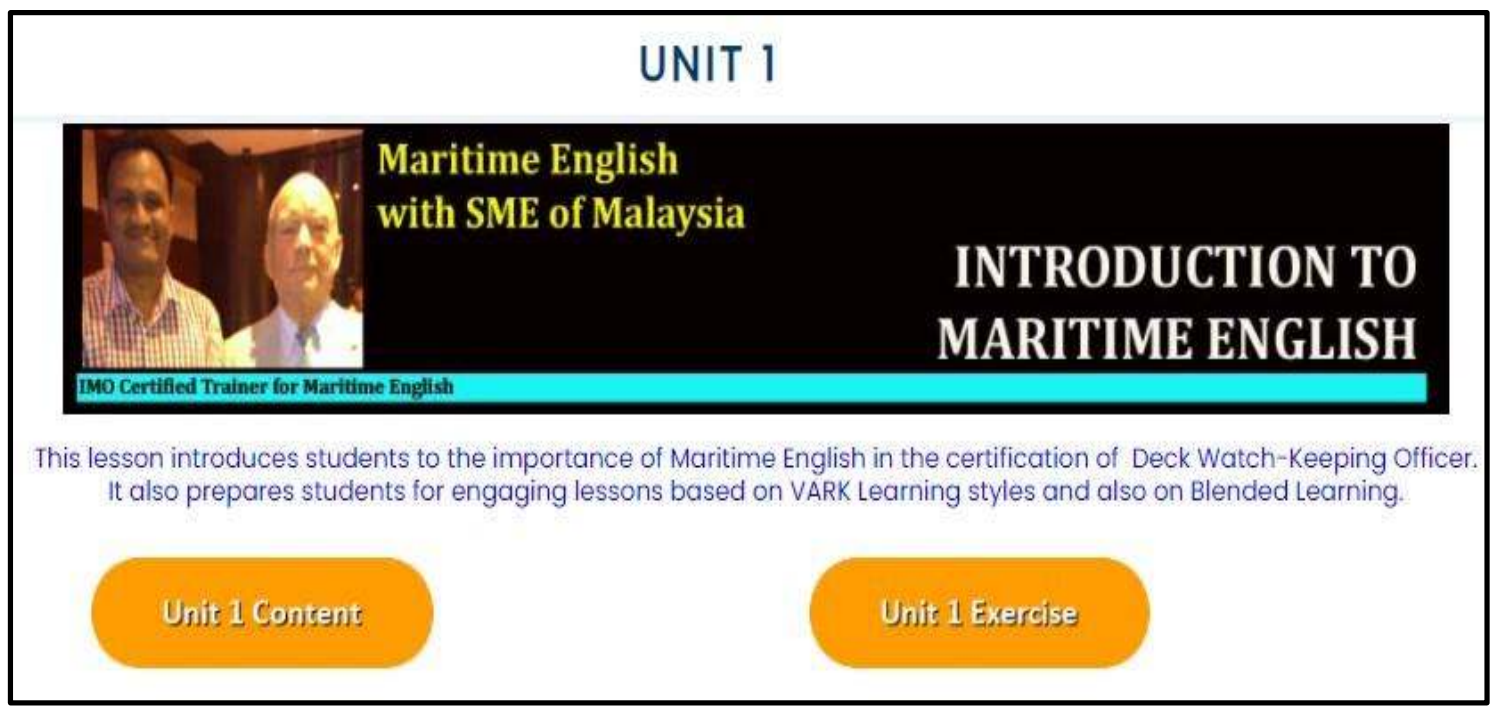

Figure 1.

Moodle LMS for Maritime English in this study.

\section{Problem Statement}


In the normal classroom, the teaching of distress and routine messages are done via Kinaesthetic learning in which students learn and practice sending and responding to VHF Radio messages by doing i.e., physically sending messages, and responding to messages. This involves bodily movement of students in classrooms as students get to involve in drills and practice, listening attentively to each word in the message and then responding effectively to the message. 'Learning by doing' like this, as emphasized by the IMO Model Course 3.17 Maritime English (p. 114) enables students to get immersed in the process of communication itself while getting themselves familiarized with the whole context of the message including the specific phrases used and the features of the message. Figures 2 below shows classroom Kinaesthetic lessons during the normal face-to-face facilitation.

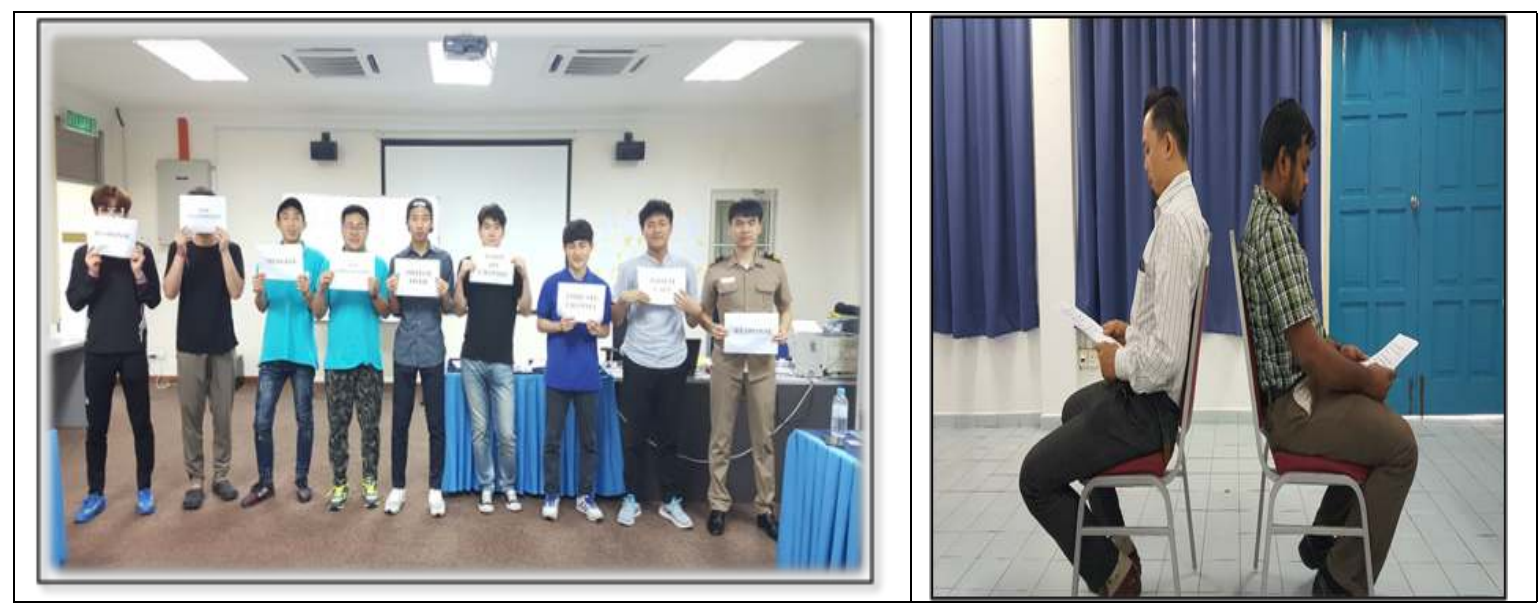

Figure 2.

Kinaesthetic lessons on '9 stages of Routine Messages' (students from Mokpo Maritime University, ROK and AWKO Batch, Malaysia)

However, all these are not possible in online distance learning (ODL) during the Covid-19 pandemic (MCO). It is a totally different scenario whereby physical movements and facilitation are limited while students are confined to their homes. Hence, the Kinaesthetic approach should be replaced with another effective approach i.e., intervention. The actual challenge was to allow students to experience the same effects on ODL compared to the normal conventional way, which lead to the same learning outcomes/objectives. Hence, due to these objectives, as the online distance learning is the only way to reach students during the lockdown, the researcher had decided to utilize Moodle LMS as an alternative to the Kinaesthetic approach in conceptualizing the distress and routine messages.

As Moodle has been part of innovative strategies in teaching, learning and assessments of the STCW courses at ALAM, it is therefore the most suitable alternative for students during the Covid-19 pandemic. Moreover, in conjunction with the studies of Frisnoiry and Darari (2020), Reham (2019), Mulhayatiah et al. (2019), Hakim et al. (2019), Cohen and Sasson (2016) and Chourishi et al. (2011), it is timely now for ALAM Moodle to be utilized further due to other engaging functions of Moodle, such as discussion forums, assignment submissions, calendar entries, student grading, interactive quizzes, class modules and tutorials for increasing students' motivation and learning outcomes. This study was therefore hoped to bring more input and new insights not only on online distance learning, but also on the use of Moodle LMS in addressing learning or in providing adequate interventions. 


\section{Methodology}

\section{Respondents}

This study was conducted on four Advanced Watchkeeping Officer (AWKO) students and 87 cadet officers at ALAM, Kuala Sungai Baru, Masjid Tanah, Melaka, Malaysia. In total, 91 respondents participated in the study. Their ages ranged from 18 to 32 years, and they were undertaking a Watchkeeping Officer's Preparatory course and Diploma in Nautical Studies with Maritime English becoming the subject of focus in both programmes. All respondents had undergone a semester-long facilitation of Maritime English with the topic Distress, Urgency, Safety and Routine Messages being the last topic in the syllabus and carrying significant weight in the final assessment. Suffice to mention also that the whole subject had been conducted via online distance learning during the MCO in Malaysia.

\section{Research design and instrumentation}

This quantitative study mainly involves the use of experiment (Moodle LMS) and survey questionnaire to obtain feedback from respondents. The experiment focused on the Unit 4 subtopic of the IMO SMCP, namely Distress, Urgency, Safety and Routine Messages. Two modules of Moodle had been developed for the experiment, as alternatives to kinesthetic learning since respondents were at home during the entire Movement Control Order 3.0 period from March to June 2021.

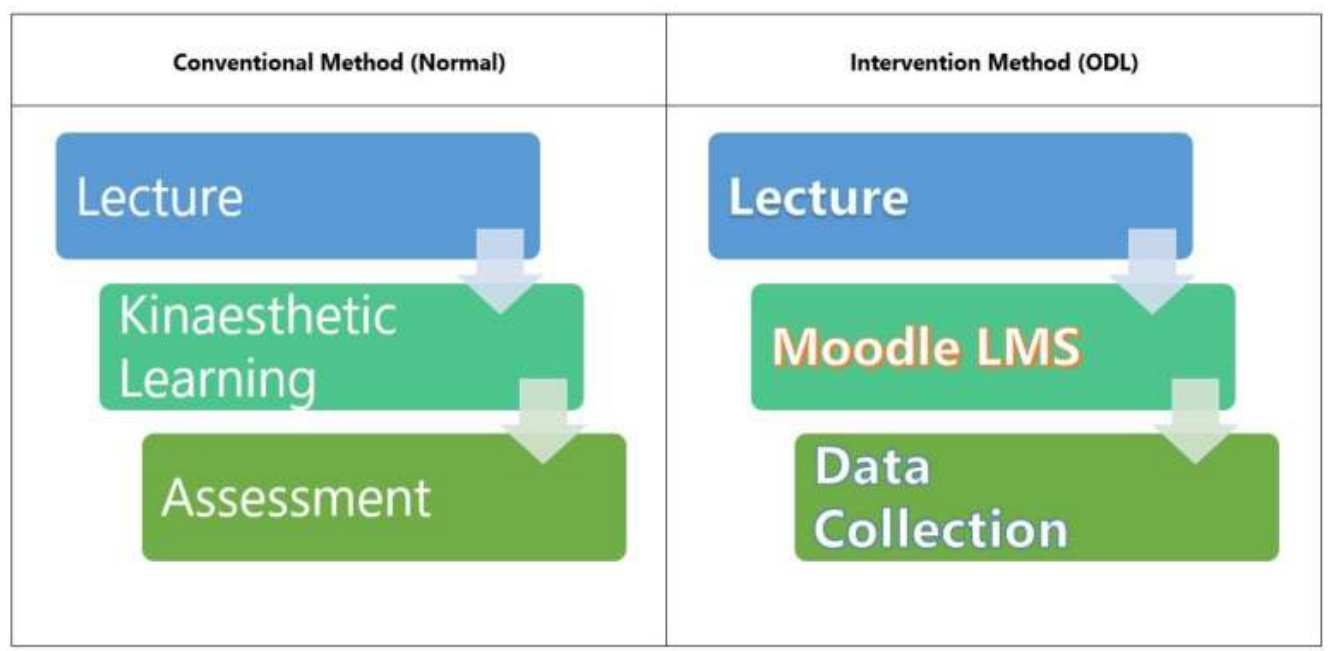

Figure 3.

Research framework of the study

Figure 3 presents the framework of this study that is represented by the 'Intervention Method (ODL)'. For the intended intervention, a lecture was conducted online in Week 15 of the studies via Microsoft Teams (PowerPoint slides lecture) followed by sharing of notes to all students. There had been discussions and Q\&A sessions between the researcher and the students for further understanding of the lessons. However, there were requests for more exercises as these two lessons are not only new; but they are also technical to students. In Week 16, the Moodle LMS of Distress and Routine Messages were made available to all students with the aim of assisting them in enhancing their understanding and conceptualization of the lessons. The data collection process took place in Week 18 as students were given two weeks to access the modules and then evaluate their experience in determining the significance of the whole 
intervention process. The collected data were then analysed by the SPSS programme for further analysis.

\section{Moodle LMS for Distress and Routine messages}

The Moodle LMS modules used in the study are Distress and Routine Messages which have been derived from the IMO SMCP lesson/topic (Distress, Urgency, Safety and Routine Messages on Marine VHF Radio). Both modules were developed on the ALAM Moodle LMS portal based on the framework of Keller's ARCS Model of Motivation (Attention, Relevance, Confidence and Satisfaction). All students had already been enrolled into the LMS for Maritime English since the beginning of the semester. Figure 4 provides a graphical representation of Question 1 of the Routine module as experimented on all respondents in this study.

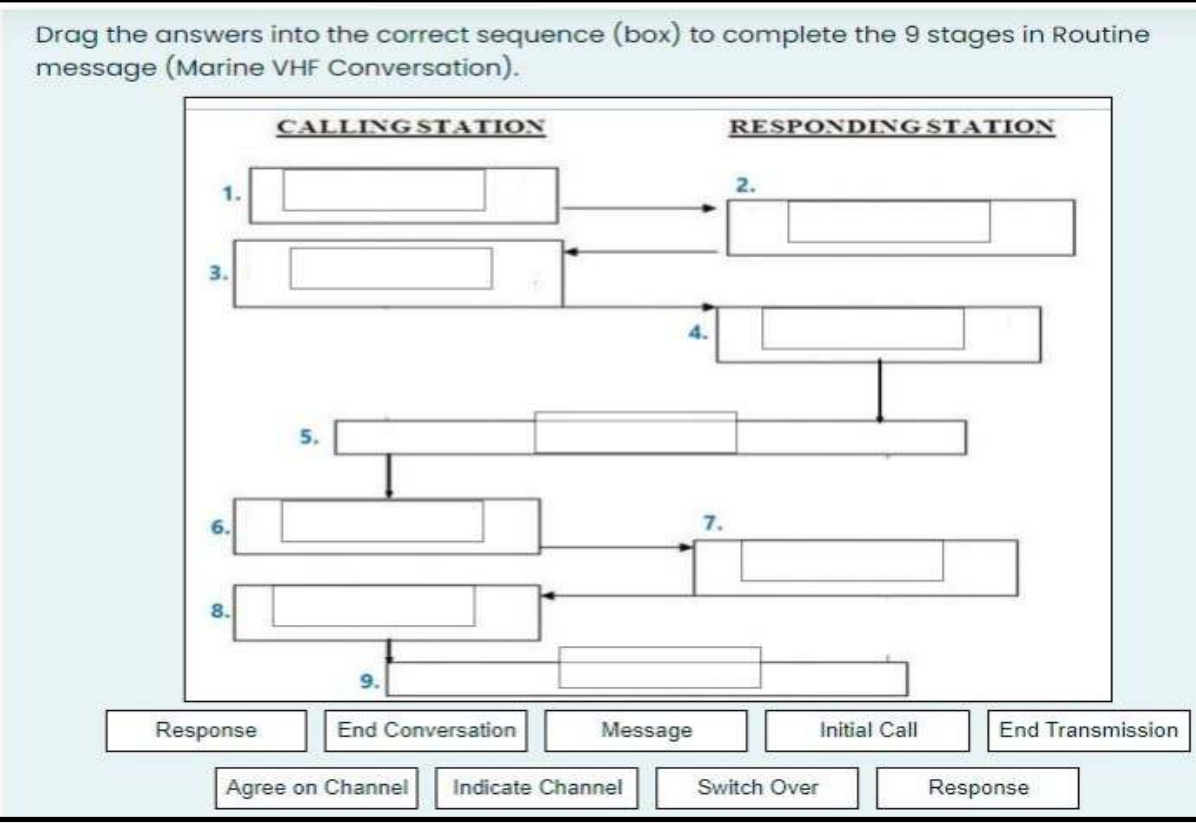

Figure 4.

LMS Module for Routine Message used in this study

There were four questions in the Routine module where respondents were required to label each stage in the Routine Message by dragging the boxes containing the stages (Response, End Conversation etc.) to the numbered sections 1-9 (Question 1), familiarizing with the phrases used (Question 2), arranging the whole ship to ship dialogue in correct order (Question 3) and supplying the correct phrases in the context/dialogue (Question 4).

\section{Survey questionnaire}

To obtain the respondents' feedback, the researcher selected Keller's Course Interest Survey (CIS, 2006) developed by Keller (2006) at Florida State University, United States. There are 34 questions in the questionnaire and the CIS questionnaire is regarded as one of the most effective measures in assessing online distance learning (ODL) in terms of student engagement, student motivation, student confidence and student satisfaction. To further capture the respondents' experience and feedback on the Moodle LMS, the questionnaire was customized to obtain responses on four major domains of learning: Attention, Relevance, Confidence and Satisfaction. 
The survey questionnaire set consisted of 34 questions which used a five point Likert Scale ranging from 1) Strongly Disagree, 2) Disagree, 3) Neutral, 4) Agree and 5) Strongly Agree. Data collection was conducted at the end of the experiment (Week 18) where all 91 respondents were asked to answer an online survey containing the self-administered questionnaire for quantitative feedback. Accordingly, a reliability test on all questions was conducted by using Cronbach coefficient alpha of the SPSS software. The Cronbach coefficient alpha value was obtained at 0.830 for all 34 questions. Nunally (1978) proposed the value of 0.7 as the accepted reliability level for research questionnaires. Hence, it can be summarized that for this study, there is a high level of reliability in all questions used. Table 1 presents the Alpha value for the survey questionnaire in this study.

Table 1.

Reliability Statistics of CIS Questionnaire used in the study

\begin{tabular}{|c|c|c|c|c|}
\hline \multicolumn{5}{|c|}{ Case Processing Summary } \\
\hline & & & $\mathrm{N}$ & $\%$ \\
\hline \multirow[t]{3}{*}{ Cases } & \multicolumn{2}{|c|}{ Valid } & 91 & 100.0 \\
\hline & \multicolumn{2}{|c|}{ Excluded $^{a}$} & 0 & .0 \\
\hline & \multicolumn{2}{|l|}{ Total } & 91 & 100.0 \\
\hline \multicolumn{5}{|c|}{$\begin{array}{l}\text { a. Listwise deletion based on all } \\
\text { variables in the procedure. }\end{array}$} \\
\hline \multicolumn{5}{|c|}{ Reliability Statistics } \\
\hline \multicolumn{2}{|c|}{$\begin{array}{l}\text { Cronbach's } \\
\text { Alpha }\end{array}$} & \multicolumn{2}{|c|}{$\mathrm{N}$ of Items } & \\
\hline & .830 & & 34 & \\
\hline
\end{tabular}

\section{Research Objectives}

The primary objective of this study was to provide alternative lessons in the form of Moodle LMS to respondents from ALAM who were affected by the Movement Control Order (MCO) in Malaysia. It was meant to help them in conceptualizing the Distress and Routine Messages of the IMO SMCP. In guiding the study/experiment, the following objectives were established:

1. To identify respondents' acceptance level of the Moodle LMS.

2. To identify respondents' confidence level with the Moodle LMS.

3. To identify respondents' satisfaction level with the Moodle LMS.

The obtained feedback will help formulate new directions in online distance learning especially in developing more effective online learning interventions for students.

\section{Research Questions}

From the above-mentioned objectives, three research questions were formulated:

1. What is the level of respondents' acceptance of the Moodle LMS in this study?

2. What is the level of respondents' confidence with the Moodle LMS in this study?

3. What is the level of respondents' satisfaction with the Moodle LMS in this study?

The answers to the research questions will provide useful feedback on the use of Moodle LMS as an alternative to conventional kinesthetic learning in the teaching of Distress and Routine 
Messages. In addressing the three research questions of the study, the four domains of the ARCS Model of Motivation were re-aligned accordingly. The Attention and Relevance domains were used to address research question 1; while the Confidence domain was used to address research question 2. Lastly, the Satisfaction domain was used to provide responses to research question 3.

\section{Research findings and discussion}

\section{What is the level of respondents' acceptance of the Moodle LMS in this study? (Analysis of Research Question 1)}

The overall answer for research question 1 can be found in the grouping of the questions that focused on the Attention dimension of the CIS questionnaire in the study. Table 2 below presents all survey questions that focused on the dimension of Attention in Keller's Course Interest Survey (CIS, 2006) together with their mean scores and standard deviations. Altogether, there were eight questions randomly arranged in the CIS survey questionnaire as questions no. $1,4,10,15,21,24,26$ and 29. To increase the reliability and validity of the questionnaire, two out of these eight questions had been constructed by Keller (2006) as 'reversed questions' (negative form). The two reversed questions were questions No. 4 and 26 and they further challenged respondents' perception and also provoked them to provide their actual feelings, experience, and opinion.

Table 2.

Survey questions focusing on the dimension of ATTENTION

\begin{tabular}{|c|c|c|c|}
\hline No. & Statement & Mean & SD \\
\hline 1. & $\begin{array}{l}\text { The instructor knows how to make us feel enthusiastic } \\
\text { about the subject matter of this course. }\end{array}$ & 4.41 & .869 \\
\hline 4. & This class has very little in it that captures my attention. & 2.57 & 1.284 \\
\hline 10. & $\begin{array}{l}\text { The instructor creates suspense when building up to a } \\
\text { point. }\end{array}$ & 3.75 & .973 \\
\hline 15. & $\begin{array}{l}\text { As a student in this class, I am curious about the subject } \\
\text { matter. }\end{array}$ & 3.92 & .934 \\
\hline 21. & $\begin{array}{l}\text { The instructor does unusual or surprising things that are } \\
\text { interesting }\end{array}$ & 4.14 & .914 \\
\hline 24. & $\begin{array}{l}\text { The instructor uses an interesting variety of teaching } \\
\text { techniques. }\end{array}$ & 4.51 & .705 \\
\hline 26. & I often daydream while in this class. & 1.89 & .849 \\
\hline 29. & $\begin{array}{l}\text { My curiosity is often stimulated by the questions asked } \\
\text { or the problems given on the subject matter in this class. }\end{array}$ & 4.38 & .771 \\
\hline
\end{tabular}

According to Table 2, the highest score in the Attention dimension was obtained by item no. 24 , which is 'the instructor uses an interesting variety of teaching techniques' with a mean 
score of 4.51. On the other hand, the lowest score in this dimension was recorded by item no. 26 , which is 'I often daydream while in this class' with a mean score of 1.89 . However, even with a low mean score, this item had been set as a negative item, which in return, needs to be viewed as positive since it provided a positive aspect of a negative perception (low score for negative means high score for positive, as prescribed by Keller, 2006). Another negative item tested in this dimension was item no. 4, 'this class has very little in it that captures my attention' with a mean score of 2.82. Again, the low mean score for this item reflects a positive situation as indicated earlier by Keller (2006). To conclude this section, all tested items in the dimension of Attention of this were considered high $(>3.75)$ and thus, this helped to address the research question. It can be said that the level of respondents' acceptance of Moodle LMS in this study was high. The next section supports this further.

The Relevance dimension of the CIS questionnaire in the study also recorded high level scores and feedback from respondents. Table 3 presents all of the survey questions that focused on the dimension of Relevance in Keller's Course Interest Survey (CIS, 2006) together with their mean scores and standard deviations. Altogether, nine questions were randomly arranged in the CIS survey questionnaire as questions no. 2, 5, 8, 13, 20, 22, 23, 25 and 28. Again, like in the Attention dimension, two out of these nine questions had been constructed by Keller (2006) as 'reversed questions' (negative form). The two reversed questions were questions no. 8 and 25 which aimed to suggest the opposite situation/option (negative) to respondents so as to be neutral.

Table 3.

Survey questions focusing on the dimension of RELEVANCE

\begin{tabular}{|c|c|c|c|}
\hline No. & Statement & Mean & SD \\
\hline 2. & $\begin{array}{l}\text { The things I am learning in this course will be useful to } \\
\text { me. }\end{array}$ & 4.60 & .555 \\
\hline 5. & $\begin{array}{l}\text { The instructor makes the subject matter of this course } \\
\text { seem important. }\end{array}$ & 4.49 & .639 \\
\hline 8. & $\begin{array}{l}\text { I do NOT see how the content of this course relates to } \\
\text { anything I already know. }\end{array}$ & 1.79 & .949 \\
\hline 13. & $\begin{array}{l}\text { In this class, I try to set and achieve high standards of } \\
\text { excellence. }\end{array}$ & 4.40 & .535 \\
\hline 20. & $\begin{array}{l}\text { The content of this course relates to my expectations and } \\
\text { goals. }\end{array}$ & 4.45 & .703 \\
\hline 22. & The students actively participate in this class. & 4.51 & .639 \\
\hline 23. & $\begin{array}{l}\text { To accomplish my goals, it is important that I do well in } \\
\text { this course. }\end{array}$ & 4.77 & .496 \\
\hline 25. & I do NOT think I will benefit much from this course. & 1.33 & .633 \\
\hline 28. & The personal benefits of this course are clear to me. & 4.65 & .584 \\
\hline
\end{tabular}


From Table 3, the highest score in the Relevance dimension was obtained by item no. 23, which is 'to accomplish my goal, it is important that I do well in this course' with a mean score of 4.77. On the other hand, the lowest score in this dimension was recorded by item no. 25 , which is 'I do NOT think I will benefit much from this course' with a mean score of 1.33. Even with a low mean score, this item had been set as a negative item, which in return, needs to be viewed as positive as it provided a positive side of a negative perception (low score for negative means high score for positive, as prescribed by Keller, 2006). Another negative item tested in this dimension was item no. 8, 'I do NOT see how the content of this course related to anything I already know' with a mean score of 1.79. According to Keller (2006), the low mean score for this item reflects a positive situation as respondents did not agree with the statement and thus rated it low in their responses. To conclude this section, all the tested items in the dimension of Relevance in this study were considered very high $(>4.40)$ and thus, to answer the research question, it can also be concluded that the level of student's acceptance of the Moodle LMS used in this study was very high.

\section{What is the level of respondents' confidence with the Moodle LMS in this study? (Analysis on Research Question 2)}

The Confidence domain of the CIS questionnaire was used to address research question 2 . Table 4 lists all of the survey questions focusing on the dimension of Attention in Keller's Course Interest Survey (CIS, 2006) together with their mean scores and standard deviations in an attempt to answer the said research question. There were eight questions under the domain of Confidence, which were randomly arranged in the CIS survey questionnaire as questions no. $3,6,9,11,17,27,30$ and 34. All questions/statements were straightforward and related to the domain with two questions constructed as negative (with the word 'difficult'). They were questions 11 and 17 which were meant to invoke further emotions and feelings of the respondents on their experience. According to Keller (2006), these will make respondents to be more careful and thoughtful upon providing the required feedback.

Table 4.

Survey questions focusing on the dimension of CONFIDENCE

\begin{tabular}{|l|l|l|l|}
\hline No. & Statement & Mean & SD \\
\hline 3. & I feel confident that I will do well in this course. & 4.46 & .688 \\
\hline 6. & You have to be lucky to get good grades in this course. & 2.79 & 1.346 \\
\hline 9. & Whether or not I succeed in this course is up to me. & 4,21 & .925 \\
\hline 11. & $\begin{array}{l}\text { The subject matter of this course is just too difficult for } \\
\text { me. }\end{array}$ & 2.55 & 1.310 \\
\hline 17. & $\begin{array}{l}\text { It is difficult to predict what grade the instructor will give } \\
\text { my assignments. }\end{array}$ & 3.48 & 1.037 \\
\hline 27. & $\begin{array}{l}\text { As I am taking this class, I believe that I can succeed if I } \\
\text { try hard enough. }\end{array}$ & 4.41 & .745 \\
\hline 30. & $\begin{array}{l}\text { I find the challenge level in this course to be about right: } \\
\text { neither too easy not too hard. }\end{array}$ & 4.34 & .819 \\
\hline 34. & I get enough feedback to know how well I am doing. & 4.37 & .755 \\
\hline
\end{tabular}

Based on the respondents' feedback and mean scores as shown in Table 4, the highest score in the Confidence dimension was obtained by item no. 3, which is 'I feel confident that I will do well in this course' with a mean score of 4.46. On the other hand, the lowest score in this 
dimension was recorded by Item No. 11, which is 'the subject matter of this course is just too difficult to me' with a mean score of 2.55. However, even with a low mean score, this item had been set as a negative item, which in return, needs to be viewed as positive as it provides a positive aspect of a negative perception (low score for negative means high score for positive, as prescribed by Keller, 2006). Another negative item tested in this dimension was item no. 2, 'You have to be lucky to get good grades in this course' with the mean score of 2.82. Again, the low mean score for this item reflects a positive situation as indicated earlier by Keller (2006). To conclude this section, all the tested items in the dimension of Confidence in this study were considered very high $(>4.40)$ and thus, to address the research question, it can be concluded that the level of student's confidence with the Moodle LMS used in this study was very high.

\section{What is the level of respondents' satisfaction with the Moodle LMS in this study? (Analysis on Research Question 3)}

For this section, the Satisfaction domain of the CIS questionnaire was used to address research question 3. Accordingly, Table 5 lists all of the survey questions relating to the dimension of Satisfaction in Keller's Course Interest Survey (CIS, 2006) together with their mean scores and standard deviations as obtained from the respondents. There were nine questions under the domain of Satisfaction randomly arranged in the CIS survey questionnaire as questions no. 7, $12,14,16,18,19,31,32$ and 33. All questions/statements were straightforward and related to the domain with only 1 question constructed as a reversed statement, 'I feel rather disappointed with this course' (Question 31). According to Keller (2006), this will make respondents to be more genuine in evaluating their experience when accessing the Moodle LMS of Distress and Routine Messages.

Table 5.

Survey questions focusing on the dimension of SATISFACTION

\begin{tabular}{|c|c|c|c|}
\hline No. & Statement & Mean & SD \\
\hline 7. & I have to work too hard to succeed in this course. & 3.96 & .942 \\
\hline 12. & I feel that this course gives me a lot of satisfaction. & 4.26 & .697 \\
\hline 14. & $\begin{array}{l}\text { I feel that the grades or other recognition I receive are } \\
\text { fair compared to other students. }\end{array}$ & 4.43 & .762 \\
\hline 16. & I enjoy working in this course. & 4.43 & .701 \\
\hline 18. & $\begin{array}{l}\text { I am pleased with the instructor's evaluations of my work } \\
\text { compared to how well I think I have done. }\end{array}$ & 4.23 & .920 \\
\hline 19. & I feel satisfied with what I am getting from this course. & 4.32 & .787 \\
\hline 31. & I feel rather disappointed with this course. & 1.18 & .437 \\
\hline 32. & $\begin{array}{l}\text { I feel that I get enough recognition of my work in this } \\
\text { course by means of grades, comments, or other feedback. }\end{array}$ & 4.22 & .904 \\
\hline 33. & $\begin{array}{l}\text { The amount of work I have to do is appropriate for this } \\
\text { type of course. }\end{array}$ & 4.49 & .673 \\
\hline
\end{tabular}


From Table 5, it is evident that the highest score in the Satisfaction dimension was obtained by Item 33, which is 'the amount of work which I have to do is appropriate for this type of course' with a mean score of 4.49. On the other hand, the lowest score in this dimension was recorded by Item 31, which is 'I feel rather disappointed with this course' with a mean score of 1.18. However, even with a low mean score, this item had been set as a negative item, which in return, needs to be viewed as positive; as it provides a positive aspect of a negative perception (low score for negative means high score for positive, as prescribed by Keller, 2006). According to Keller (2006), the low mean score for this item reflects a positive situation as respondents did not agree with the statement and thus rated it lowly in the questionnaire. To conclude this section, all the tested items in the dimension of Satisfaction in this study were considered very high $(>3.96)$ and thus, to answer the research question, it can also be concluded that the level of student's Satisfaction with the Moodle LMS used in this study was very high.

\section{Conclusion}

The first conclusion that can be made from this study is that, on average, all respondents have provided a high level of feedback and responses to the questionnaire which reflected their pleasant experience when accessing the Moodle LMS for Distress and Routine Messages in this study. In a more specific situation, all four domains of the ARCS Model as embedded in the CIS questionnaire recorded high scores, which reflected the positive experience of the respondents.

Hence, it can be summarized that the following questions/statements and their respective mean scores reflect this favourable situation/experience. Table 6 summarizes this section by listing all statements from the four domains that obtained high mean scores from respondents (4.26 to 4.65), helping to conclude respondents' perception, opinion, and experience in accessing the Moodle LMS of Distress and Routine Messages used in this study.

Secondly, the positive outcomes of study also indicated the researcher's utmost effort in providing the required alternative to students when the usual/conventional teaching approach could not be used due to physical restrictions during the MCO. Indeed, this study provides valuable input to maritime education and training institutions (METIs) especially in Malaysia as it gives further directions on the learning interventions to be made in online distance learning. It is undeniable that lecturers are responsible for providing effective alternative lessons to students during the time of uncertainty as experienced during the Covid-19 pandemic worldwide. Hence, this second conclusion is well-supported by earlier findings by Tanveer et al. (2020) that online distance learning is not only about the internet communication and facilities, but also concerns about trainer's blended technology skills, competencies, and extra effort. It is a well-known fact that the sudden shift to online distance learning has posed immense challenges to both educators and students (Li and Lalani, 2020; Lisnani et al, 2020; Tanveer et al., 2020 and Tam, 2020).

Finally, the findings of this study provide the missing link in online distance learning of the STCW courses in Malaysia. It is the Instructional Design (ID) and Multimedia Authoring skills that must be further highlighted, nurtured, and mastered in order to be successful in developing Moodle LMS content. It is further anticipated that more related studies could be conducted on the significance of these two skills (Instructional Design and Multimedia Authoring). In conjunction with this aspiration, it is in the researcher's wish that there shall be more descriptive and detailed guidelines/manual in Moodle for everyone's benefit so that more 
STCW trainers/researchers could take up the effort to develop interactive content for STCW courses.

Table 6.

Survey questions from all 4 domains that summarize the positive outcomes of this study

\begin{tabular}{|l|l|l|l|}
\hline No. & Statement & Mean & Dimension \\
\hline 1. & $\begin{array}{l}\text { The instructor knows how to make us feel } \\
\text { enthusiastic about the subject matter of this course }\end{array}$ & 4.41 & Attention \\
\hline 24. & $\begin{array}{l}\text { The instructor uses an interesting variety of teaching } \\
\text { techniques. }\end{array}$ & 4.51 & Attention \\
\hline 2. & $\begin{array}{l}\text { The things I am learning in this course will be useful } \\
\text { to me. }\end{array}$ & 4.60 & Relevance \\
\hline 5. & $\begin{array}{l}\text { The instructor makes the subject matter of this course } \\
\text { seem important. }\end{array}$ & 4.49 & Relevance \\
\hline 20. & $\begin{array}{l}\text { The content of this course relates to my expectations } \\
\text { and goals. }\end{array}$ & 4.45 & Relevance \\
\hline 28. & $\begin{array}{l}\text { The personal benefits of this course are clear to me. } \\
\text { I feel confident that I will do well in this course. }\end{array}$ & 4.65 & Relevance \\
\hline 3. & $\begin{array}{l}\text { I find the challenge level in this course to be about } \\
\text { right: neither too easy not too hard. }\end{array}$ & 4.34 & Confidence \\
\hline 30. & $\begin{array}{l}\text { I feel that this course gives me a lot of satisfaction. } \\
\text { I enjoy working in this course. }\end{array}$ & 4.26 & Satisfaction \\
\hline 16. & $\begin{array}{l}\text { I feel satisfied with what I am getting from this } \\
\text { course. }\end{array}$ & 4.32 & Satisfaction \\
\hline 19.43 & Satisfaction \\
\hline
\end{tabular}

\section{Acknowledgement}

The author gratefully acknowledges the significant contributions of Professor John M. Keller who develops the ARCS Model of Motivation used in this study.

\section{References}

Arkorful, V. and Abadioo, N. (2014). The role of e-learning, the advantages and disadvantages of its adoption in higher education. International Journal of Education and Research, 2, 397-410.

Chourishi, D. Buttan, C.K., Chaurasia, A. and Anita, S. (2011). Effective e-learning through Moodle. International Journal of Advanced Technology \& Engineering Research (IJATER), 1, 34-38.

Cohen, D. and Sasson, I. (2016). Online quizzes in a virtual learning environment as a tool for formative assessment. Journal of Technology and Science Education, 6, 3, 188-208. 
Frisnoiry, S. and Darari, M.B. (2020). Utilization of Moodle in learning. IOP Conference Series: Journal of Physics: Conference Series, 1462.

Gunduz, N. and Ozcan, D. (2017). Implementation of the Moodle system into EFL classes profile: Issues. Teacher Professional Development, 19, 51-64.

Keller J.M. (1979). Motivation and instructional design: A theoretical perspective. Journal of Instructional Development., 2(4):26 -34.

Keller, J.M. (2006). Development of Two Measures of Learner Motivation. Florida: Florida States University, Ver. 060222, 1-9.

Keller, J.M. (2010). Motivational design for learning and performance: the ARCS model approach. New York: Springer.

Li, C. and Lalani, F. (2020). The COVID-19 pandemic has changed education forever. This is how. Retrieved at https://www.weforum.org/agenda/2020/04/coronavirus-education-global-

covid19-online-digital-learning/

Lisnani et al. (2020). Designing Moodle features as e-learning for learning mathematics in COVID-19 pandemic. Journal Physics: Conference Series, $1657012024,1-9$.

Noawanit, S.F., Jintavee, K., Bundit, P. and Maneerat, L. (2015). E-learning system to enhance cognitive skills for learners in higher education. Procedia-Social and Behavioural Science, 174, 667-673.

Nunnally, J. C. (1978). Psychometric theory (2nd ed.). New York: McGraw-Hill.

Sucheta, V.K., Radhika, M.P. and Manohara, P.M. (2018). Adaptive user interface for Moodle based e-learning system using learning style. Procedia Computer Science, 135, 606-618.

Tam, G. (2020). 3 Ways the coronavirus pandemic could reshape education. Retrieved at www.weforum.org/agenda/2020/03/3-ways-coronavirus-isreshaping-education-and-what-changes-might be-here-to-stay.

Tanveer, M., Bhaumik, A., Hassan, S., \& Ul Haq, I. (2020). Covid-19 pandemic, outbreak educational sector and students online learning in Saudi Arabia. Journal of Entrepreneurship Education, 23(3). 